\title{
Control of voluntary intake of precision-chopped silages by ruminants: a review
}

\author{
JP Dulphy ${ }^{1}, \mathrm{M}$ Van Os ${ }^{2}$ \\ ${ }^{1}$ Station de recherche sur la nutrition des herbivores, \\ Centre de Theix, Inra, 63122 Saint-Genès-Champanelle, France; \\ 2 Department of Ruminant Nutrition (ID-DLO), DLO, Institute for Animal Science and Health, \\ PO Box 160, 8200 AD Lelystad, The Netherlands
}

(Received 12 May 1995; accepted 5 January 1996)

\begin{abstract}
Summary - The aim of this review is to provide a better understanding of the ways in which ruminants control their voluntary intake of finely-chopped silages. Silages with an excellent conservation quality can be ingested at similar levels to the corresponding fresh or dry forages. Intake levels decrease when conservation quality decreases. The implicated physiological mechanisms for this phenomenon are discussed in this review. Poorly preserved silages may have low palatibility, decreasing the animal's motivation to ingest. At the ruminal level, the physical control of intake is generally not involved. On the other hand the fermentation products present in silage seem to induce a high and rapid level of satiation, out of proportion to their relatively low quantity. At the metabolical level some limiting factors may also exist (eg, a poor balance between amino acids and energy, and high levels of acids to be metabolized). Fermentation products induce most of the observed reactions. For well-preserved silages, high quantities of lactic and acetic acids limit intake. Their effects seem to be additive, which explains the observation that low $\mathrm{pH}$ often has a negative action. The negative effect of moisture is generally strengthened by that of the acids. For poorly-preserved silages, products of protein decomposition must be considered in addition to volatile fatty acids. The effect of $\mathrm{N}$-compounds is less clearly explained than that of acids. For example, ammonia alone generally seems to have no direct effect. However it is clear that $\mathrm{N}$-compounds taken together have a negative effect on appetite. It can be concluded that the negative effects of poor quality silages are multifactorial; each fermentation product alone has a low effect, but the sum of all the components must be considered. Moreover, it is apparent that some physiological mechanisms are used to control silage intake, which explains the complexity of the studies on this subject.
\end{abstract}

intake / maize / grass / silage / fermentation

Résumé - Régulation de la quantité ingérée d'ensilages à brins courts chez les ruminants : revue bibliographique. L'objet de ce mémoire est de tenter de comprendre comment lingestion des ensilages à brins courts est contrôlée chez le ruminant. Il est rappelé tout d'abord que les ensilages qui ont une qualité de conservation excellente sont ingérés en quantité équivalente à celle du fourrage vert ou 
du foin correspondant. Les quantités ingérées diminuent ensuite au fur et à mesure que la qualité de conservation se dégrade. Les mécanismes physiologiques impliqués sont décrits. Ainsi, les ensilages mal conservés ont parfois une appétibilité faible qui diminue la motivation des animaux à ingérer. Au niveau ruminal la régulation physique de l'ingestion n'est en général pas en cause. En revanche, les produits de la fermentation semblent avoir un effet rassasiant notable et rapide, proportionnel à leur quantité. Au niveau métabolique il peut aussi exister des facteurs limitants (mauvais équilibre acides aminés/énergie, apport élevé d'acides à métaboliser). Les produits qui entraînent les réactions observées sont ceux issus des fermentations. Pour les ensilages bien conservés les acides lactique et acétique, en quantités élevées, sont des facteurs limitant l'appétit. Leurs effets semblent être additifs, d'où un rôle souvent négatif de $\mathrm{pH}$ faibles. L'effet négatif de l'humidité est en général renforcé par celui des acides. Pour les ensilages mal conservés, aux AGV, se rajoutent des produits de décomposition des MAT. L'effet de ces produits est moins clair que celui des acides. L'ammoniac par exemple ne semble pas avoir d'effet dans la majorité des cas. II est clair cependant que plus ces produits augmentent plus l'appétit des animaux diminue. On peut conclure que les effets négatifs de la mauvaise qualité de conservation des ensilages sont plurifactoriels, chaque produit de la fermentation ayant peu d'effet seul, mais l'ensemble ayant des effets importants. En outre on peut considérer que plusieurs mécanismes physiologiques sont utilisés pour limiter l'appétit, ce qui rend les études sur le sujet d'autant plus complexes.

ingestion / maïs / herbe / ensilage / fermentation

\section{INTRODUCTION}

In order to explain variations in forage intake, and to be able to predict voluntary intake levels, it is necessary to know the factors and mechanisms that are involved in voluntary intake and how they act on its regulation. Ensiled grass and maize are now widely used as forage in cattle and dairy production throughout Europe and North America. However, the voluntary intake of these silages varies greatly and is generally lower than that of the corresponding fresh grass or hay (Demarquilly, 1973; Dulphy et Michalet-Doreau, 1981). Because animal performance is positively related to the level of voluntary intake, a great deal of research has been undertaken in the last three decades to explain the origin of lower levels of intake and intake variations of ensiled forages. One major finding is that daily intake is affected by numerous silagerelated factors.

The aim of this paper was to review the current state of our knowledge of silagerelated factors affecting intake, and the mechanisms involved. The first part of the review outlines the major conclusions concerning the voluntary intake of silage and some associated phenomena. The second part analyses the principal mechanisms regulating intake and the silage characteristics that affect voluntary intake.

\section{REVIEW OF MAIN RESULTS}

\section{Voluntary intake}

The fermentation quality of silages can be characterized by their levels of certain fermentation products. Quality classification levels based on fermentation products have been proposed by several authors including Dulphy and Demarquilly (1981). Wellpreserved silages can be characterized by the following figures: $\mathrm{NH}_{3}-\mathrm{N}$ under $5 \%$ of total nitrogen $(\mathrm{N})$, soluble $\mathrm{N}$ under $50 \%$ of total $\mathrm{N}$, volatile fatty acids (VFA) under 25 $\mathrm{g} / \mathrm{kg}$ dry matter (DM), and no propionic or butyric acids.

In bovine animals, the DM voluntary intake of good quality grass silages, based 
on the classification of Dulphy and Demarquilly (1981) was close to that of the initial fresh forage ( $98 \%$ for eight comparisons; Dulphy et al, 1984). From the results of different trials, Dulphy et al (1987) proposed a mean decrease of $3-5 \%$. Compared to hays prepared with the same initial green forages, the intake of good silages by dairy cows is sometimes better $(+6 \%$ for eight comparisons in the literature), and sometimes slightly lower $(-5.5 \%$ for three comparisons at INRA) (Dulphy, 1987). Moreover, in their trials with heifers, Dulphy and Rouel (1988) observed a hay intake 5\% higher than that of the initial fresh forages (12 comparisons). Nevertheless Dulphy et al (1987) suggested that the intake of good grass silages should be set at 3-5\% under that of well-prepared corresponding hays (field-cured with fine weather).

In sheep, Dulphy and Michalet-Doreau (1981) found a $17 \%$ reduction of silage intake compared with the original forage (64 comparisons). In this study the intake of fresh forage was determined by long-day measurements, whereas silage intake was measured during the winter over short day lengths. In an experiment where the animals were fed the same hay throughout the year, Michalet-Doreau and Gatel (1983) also found a reduction in intake when the day length decreased. The difference in intake between silage and grass observed by Dulphy and Michalet-Doreau (1981) may therefore have been due to photoperiodicity. This hypothesis is supported by the study of Andrieu et al (1981), who found no difference in intake between well-preserved silages and hays prepared from the same original herbage and fed simultaneously to sheep. There are almost no other results in the literature on this problem, because, from a practical point of view, only comparisons during the same period are interesting and scientifically acceptable. Also, only sheep seem sensitive to this effect of photoperiodicity.
It can thus be concluded that the daily intake of well-preserved grass silages is the same as or only slightly lower than that of hay or green herbage from the same sward. This daily intake is therefore dependent on classical characteristics of the forage, such as rate of digestion, $\mathrm{N}$ and cell wall contents, which will not be considered here.

Poorly-preserved silage, characterized by high levels of fermentation products (VFA and protein degradation products; see Dulphy and Demarquilly, 1981), results in lower levels of dry matter intake. Negative correlations have been observed between intake and the concentrations of ammonia, acetic acid and moisture content in silages for sheep (Wilkins et al, 1971; Brown and Radcliffe, 1972; Demarquilly, 1973) and beef cattle (McCarrick et al, 1965; Harris et al, 1966; McCullough, 1966; Waldo et al, 1968; Rook and Gill, 1990). A negative correlation was also found between intake and propionic acid levels for sheep (Brown and Radcliffe, 1972). Dulphy and Michalet-Doreau (1981) linked the levels of fermentation products quantitatively to their effects on intake. In sheep they calculated intake reductions of: $6.3 \mathrm{~g} / \mathrm{kg} \mathrm{LW} 0.75$ when $\mathrm{pH}$ increased by 1 unit; $7.0 \mathrm{~g} / \mathrm{kg} \mathrm{LW} 0.75$ per 10 point increase in the $\mathrm{NH}_{3}-\mathrm{N}$ content expressed as a percentage of the total $\mathrm{N} ; 7.8 \mathrm{~g} / \mathrm{kg}$ LW 0.75 when the acetic acid concentration increased by $100 \mathrm{~g} / \mathrm{kg} \mathrm{DM}$; and $5.5 \mathrm{~g} / \mathrm{kg} \mathrm{LW} 0.75 \mathrm{per}$ 1 mole increase in the total VFA concentration per $\mathrm{kg}$ DM. The calculated effects are not cumulative since the concentrations of these fermentation products are closely correlated.

The negative effects of fermentation products on DM intake can also be demonstrated by comparing the intake of naturally fermented silages with that of the same herbage ensiled with a fermentation-inhibiting additive such as formic acid (Castle and Watson, 1970; Waldo et al, 1971, 1975; Waldo, 1977; Jarrige et al, 1981). Comparing the intake of these two types of silage 
in cattle (21 comparisons), Dulphy and Michalet-Doreau (1981) found a $12.5 \%$ average increase in DM intake when directly cut grass was preserved with formic acid, and an increase of $6-9 \%$ in intake when the grass was wilted before ensiling. An additional increase in intake was observed when the level of formic acid was doubled $(+4.6 \%$ in a trial with sheep; Dulphy et al, 1975). Elsewhere, the same tendency can be observed with a new additive which restricts fermentation, Maxgrass. For example, in a trial by Kennedy (1990) this additive increased intake by $8 \%$ in beef cattle, compared to the use of formic acid.

The data (table I) summarized by Dulphy et al (1987) support the positive influence of restricted fermentation and wilting on intake by heifers and dairy cows. No similar compilation for sheep has been made. Nevertheless, Dulphy and Michalet-Doreau (1981) found a $5 \%$ higher intake by sheep of a formic-acid-preserved silage, whereas Chiofalo et al (1992) observed a 17\% higher intake! However some differences between sheep and cattle must be noted. For maize silages sheep do not react to DM (Demarquilly, 1994), whereas cattle are very sensitive. For grass silages reactions are com- parable for the two species (Dulphy and Michalet-Doreau, 1981).

\section{Intake behaviour and rumination}

Voluntary daily intake is determined by meal size and the number of meals eaten per day. Detailed monitoring of the daily intake pattern (Dulphy et al, 1984) and the quantity eaten during the first meal after feeding (main meal) (Dulphy, 1985) indicated that ruminants exhibit signs of satiation earlier when fed grass silage rather than hay.

The intake pattern of cattle fed silage is characterized by a relatively short main meal (Gill et al, 1988) and a high number of small meals during the day (Thiago et al, 1992b). Unlike hay, therefore, silage probably contains components that have an impact on intake behaviour. In well-preserved silages these components seem to have little or no effect on total daily intake. Sheep compensate for a lower intake during the main meal of the day by taking more meals subsequently during the day or by increasing their size (Dulphy, 1985). The fermentation products that build up as a result of poor preservation cause a further reduction in intake

Table I. DM of grass silage and intake by heifers and cows (100\% defined for barn-dried hay) (Dulphy et al, 1987); figures given without the distribution of concentrates.

Silage DM content (\%)

DM intake

Silage without additive

Silage with formic acid

$\begin{array}{lrrr}\text { Heifers } & 17 & 76 & 87 \\ & 20 & 81 & 91 \\ & 23 & 86 & 95 \\ & 35 & 95 & 100 \\ \text { Dairy cows } & 17 & 84 & \\ & 17 & 87 & 91 \\ & 20 & 90 & 96 \\ & 23 & 96 & 100\end{array}$


during the main meal but also reduce the number of subsequent meals and the intake during them (Chiofalo et al, 1992). This suggests that satiation lasts throughout the day (Baumont et al, 1993), preventing the animals from compensating for the reduced intake at the main meal.

The intake rate during the day, as with that during the main meal, is a parameter that distinguishes between forages of different ingestibilities. However, this intake rate is comparable between silages and fresh forages or hays (Jarrige et al, 1995). Sometimes silage is more rapidly consumed than fresh forage. In the experiments of Dulphy et al (1984) there was little evidence for sheep that the intake rate during the main meal was affected by preservation quality. This contradiction, however, does not exclude the negative effects of fermentation products, the duration of intake then being shorter. However, the lower intake rates observed in heifers during the day and at the main meal suggest that they are more sensitive to variations in preservation quality of silage (Dulphy and Demarquilly, 1977; Dulphy et al, 1984).

The shorter time spent ruminating by cattle (Thiago et al, 1992b), dairy cows (Van Bruchem et al, 1991) and sheep (Chiofalo et al, 1992) when fed silage, rather than hay, or when silage preservation is poor (Teller et al, 1989), is merely a consequence of the lower intake and not its cause.

In conclusion, fermentation products in silages alter intake behaviour in such a way that signs of satiation are observed shortly after ingestion.

\section{Associated ruminal phenomena}

According to Thiago and Gill (1986), animals which receive a ration of grass silage do not use their entire rumen capacity. This was confirmed by Gill et al (1988) and Baumont (1989) (table II), and by Chiofalo et al (1992), and is probably the cause of the longer time-lag between the end of the main meal and the beginning of rumination (Chiofalo et al, 1992) observed for silages compared to hays.

Clancy et al (1977b) reported impaired rumen motility after a ruminal infusion of juice pressed from silage. No disturbance, however, was observed by Chiofalo et al (1992) with a poorly ingested silage. Thiago et al (1992b) observed slightly lower contractile activity in cattle fed silage than in

Table II. Effect of the type of diet on quantities of reticulo-ruminal (RR) content just after the main meal (Baumont, 1989).

$\begin{array}{lrrr}\text { RR content (\% live weight): } & & & \\ \text { Dry } & 2.8 & 2.3 & 1.9 \\ \text { Fresh } & 21.3 & 18.3 & 1.5 \\ \text { DM intake (\% live weight) } & 1.75 & 2.01 & \\ & & & 13 \\ \text { Composition of the diets: } & 8 & 17 & 73 \\ \quad \text { Crude protein (\% DM) } & 54 & 71 & \\ \text { OM digestibility (\%) } & & & \end{array}$


those receiving hay. In their study the liquid passage rate was higher with the silage ration than with the hay ration.

\section{INTAKE-REGULATING MECHANISMS}

Daily voluntary food intake is regulated by long-term control factors such as physiological state, production level and environment, but also by short-term factors. These include a variety of signals ranging from interconnected mechanisms operating at the oropharyngeal, ruminal and metabolic levels to one or more signals that determine the beginning and end of each meal (Grovum, 1987). Because the intake of silages of excellent quality is similar to that of hay or fresh forage from the same crop, it can be assumed that, with this type of silage, the regulating mechanisms at the three levels mentioned, act in the same way as for the intake of hay or fresh material. Intake decreases when the concentrations of fermentation products in silage increase, which suggests there is a shift in the way satiation signals are generated. The extent to which the regulation mechanisms affecting the oropharyngeal, ruminal and metabolic levels control the silage intake will therefore be discussed.

\section{Oropharyngeal level}

Palatibility is widely acknowledged to be a factor that determines forage intake (Greenhaigh and Reid, 1971; Grovum, 1987). Palatibility can be defined as the sensory response of an animal to its food, as demonstrated by changes in eating rate and the willingness to accept the food. It is influenced by food-related factors, such as taste, smell and texture. Palatibility has a definite impact on the intake of forages of low nutritive value, such as straw (Greenhalgh and Reid, 1971).
Compared with normal straw, higher intakes were reported for sheep fed straw supplemented with sodium glutamate as a taste-improver (Colucci and Grovum, 1993), while lower intakes were observed with urea-treated straw that still contained high concentrations or urea, which is known to be unpalatable to sheep (Dulphy et al, 1992).

These observations, and the fact that silages contain volatile fermentation products and other compounds that supposed to have strong taste sensations, tend to support the contention that palatibility is an influential factor in the intake of poorly-preserved silages. The hypothesis is further supported by the higher silage intake reported for anosmic sheep (Michalet, 1975), and the increase in intake observed when flavouring compounds were added to silage (Henderson and Anderson, 1986; Corkum et al, 1994).

From a great number of silage fermentation products (lactic and volatile organic acids, amino acids, ammonia and amines) Buchanan-Smith (1990) tried to identify those responsible for lowering palatibility. Acetic acid had only negative influences, which was a result of the product itself rather than acidity in general, since the same level of acid in a combination of lactic and acetic acids (1.5:1) did not depress intake. Other studies of the effects of acids in silage on palatibility have yielded discrepant results. The negative effects reported by Orth and Kaufmann (1966) and McLeod et al (1970) were not confirmed in the works of McLeod and Wilkins (1970) or Ndwiga et al (1990), while Grovum and Chapman (1988) found a lower palatibility for acidified pelleted lucerne (50 $\mathrm{g} \mathrm{HCl}$ added $/ \mathrm{kg} \mathrm{DM})$ in sham-fed sheep.

The possible negative effect of fermentation products on silage palatibility, when expressed in terms of intake rate, was demonstrated by Dulphy et al (1975) and Dulphy et al (1984). Lower intake rates were sometimes found with poorly-preserved 
silages than with well-preserved silages. In contrast, Chiofalo et al (1992) reported that the intake rate for sheep was not affected by fermentation quality. There are two possible explanations of this unexpected result: sheep are less sensitive than heifers to the presence of fermentation products (Dulphy et al, 1984), and in well-preserved silages there are already substantial concentrations of fermentation products. Furthermore, it is possible that with silage the shorter duration of the main meal and the longer intervals between the main meal and subsequent small meals, are partly a consequence of a lower palatibility. The same trend, however, was found when intake patterns of high and low-quality hays were compared (Gatel, 1984; Baumont et al, 1990), showing that palatibility plays a significant role in short term satiation (ie, there is low motivation to ingest low-quality hays).

In conclusion, an effect of palatibility is possible but not very clear. Although acetic acid was generally the only fermentation product found to act negatively on palatibility, there is still the possibility that different fermentation products acting together have a more general effect on palatibility. Moreover, as emphasized by Buchanan-Smith (1990), it is important, when determining the influence of palatibility on intake, to separate the effects of palatibility per se on intake control from those of post-ingestive signals.

\section{Ruminal level}

\section{Physical aspects}

At the ruminal level, silage intake could be limited if the maximum rumen distension is reached (the fill effect; Campling and Balch, 1961). Forage digestion rate and rumen turnover rate of undigestible particles must therefore be considered, as well as digestibility (Van Vuuren, 1994). However, as seen earlier, various studies have shown that ruminants fed grass silage do not use their entire rumen capacity (Waldo et al, 1965; Campling, 1966; Lawlor and O'Shea, 1967; Thiago et al, 1992b; Chiofalo et al, 1992). This was also found when well- and poorly-preserved silages were compared (Dulphy et al, 1975; Chiofalo et al, 1992).

The effects of fermentation products on digestibility are considered to be low (McDonald et al, 1991; Dulphy and Demarquilly, 1991), although the fibre and ash contents may be slightly greater in lower quality silages (Demarquilly, 1973). Lower digestibility has been mainly observed for wilted silages, but there is no effect on intake, which is generally higher with this type of silage. Teller et al (1989), however, found that wilting did not alter ruminal digestion. Digestibility is also decreased when losses in effluent are high. Hence, differences in intake between fresh grass and silage or between well- and poorly-preserved silages cannot be explained by differences in digestibility except, perhaps, for very wet silages.

The rate of DM disappearance from the reticulo-rumen is comparable (Chiofalo et al, 1992) or higher with silage than with hay (Thiago et al, 1992a). The cellulolytic activity of the rumen microbes is also similar in animals fed silage or hay (Dulphy et al, 1975 ), and preservation quality seems to have no effect on digestion rate in the rumen.

In addition, Thiago et al (1992a) observed a higher passage rate from the rumen for both the liquid and solid phases with silage than with hay, although the intake of silage was lower. This finding and the conclusions of Gill et al (1988) show that rumen fill is not the major factor involved in the voluntary intake of well- and poorly-preserved silages. It could, however, be the case if rapid gas production leads to increased rumen distension (Prates et al, 1986; Thiago et al, 1992a). This is feasible when the 
voluntary intake of silage is compared with that of hay, but not in the comparison of the voluntary intake of hay and the corresponding fresh forage, which contains considerable concentrations of soluble and rapidly fermentable components.

From experiments in which the intake of maize silage increased after the addition of urea (Demarquilly et al, 1971; Thomas et al, 1975) and from others in which fish meal was added to grass silages (Gill and England, 1984; England and Gill, 1985), it was concluded that the rumen digestion rate might act as a limiting factor in silage intake when the silage contains insufficient nitrogen to achieve optimum microbial digestion. This hypothesis was rejected by Thomas et al (1980) and Gill and al (1987), who suggested that the increased intake was more likely of metabolic origin and due to a better balance between the energy and amino acid supplies.

\section{Chemical aspects}

Both grass and maize silages are characterized by considerable concentrations of soluble components, sometimes in addition to the readily fermentable carbohydrates. It is therefore possible that silage ingestion leads to a rapid rise in concentrations of fermentation products in the rumen, and thereby induces a state of satiation. The satiation state can be initiated by signals from chemo-receptors situated in the rumen that react on chemical alterations in the rumen environment, such as $\mathrm{pH}$, osmolality or volatile fatty acid concentrations (Gill et al, 1986). High concentrations of lactic acid may also have a negative effect.

It is conceivable, although it has not been directly proven, that this kind of chemical regulation occurs during the main meal. Thiago et al (1992a) found a more rapid drop in $\mathrm{pH}$ during silage ingestion than during hay ingestion, but a much slower increase in ammonia concentrations. This is because rumen fermentation begins more quickly with silage, and probably because of a small effect of silage acids on ruminal $\mathrm{pH}$. Elsewhere Clancy et al (1977b) observed a considerable disturbance of rumen motility after an intra-ruminal infusion of juice pressed from silage. These authors ascribed this to local action by fermentation products on the chemo-receptors situated in the rumen wall. The quantities infused, however, exceeded those ingested under normal conditions, even when poorly preserved silages were fed (Chiofalo et al, 1992). Intraruminal infusions of silage juice in the experiments of Buchanan-Smith and Phillip (1986) resulted in lower intake during the subsequent main meal. However, the fermentation products responsible for the intake depression could not be identified. In another study Snyder et al (1983) detected no effects of silage neutralization by bicarbonate during intake, even when rumen $\mathrm{pH}$ increased.

Under normal conditions, the ingested silage is buffered by the saliva produced and mixed with the digesta pool in the rumen. The direct effect of silage $\mathrm{pH}$ on rumen $\mathrm{pH}$ is therefore probably small (Thomas and Wilkinson, 1975). Wide variations in rumen ammonia and VFA concentrations are more common as a consequence of silage intake. The highest concentrations, however, are found for silages with the greatest intake, such as wilted silages (Teller et al, 1989). In animals receiving hay or silage, Chiofalo et al (1992) observed the lowest $\mathrm{pH}$ and highest osmolality and VFA concentrations at the end of the main meal of hay, for which the intake was significantly higher.

There remain many areas of uncertainty. According to Thomas and Wilkinson (1975), the positive effect of silage neutralization on intake is not exerted in the rumen. Feedback signals affecting the intake may be also rapidly initiated by the duodenum (Bueno, 1975), liver or nervous system. Rapid satiety could also be caused by a 
learning mechanism, since it is not observed with the first silage meals but begins 4-5 days later (Dulphy, 1972). This, however, needs to be confirmed.

Precise kinetic studies of ruminal characteristics with regard to chemo-receptors are needed to better understand this potential mechanism, while closely monitoring the feeding activity. It is very probable that some chemo-receptors are sensitive to acetic acid (Baile, 1975; Forbes, 1980). Moreover Clancy et al (1977b) reported that rumen motility was considerably disturbed when badly preserved silage was given without allowing the animals an adaptation period. Likewise Sissons et al (1986) observed a lower ruminal motility when silage was fed than with a hay diet. In contrast, Chiofalo et al (1992) observed no problem with their silages.

\section{Metabolic level}

Because of the lack of any clear evidence that silage intake is influenced by regulating factors on the oropharyngeal or ruminal levels, it has been suggested that silage intake leads to metabolic disorders, such as acidosis or an imbalance between the energy and nitrogen supplies, that could limit voluntary intake. If sensory or digestive limitations are not observed, chemoreceptors may be stimulated, as well as receptors located elsewhere in the organism. This was suggested by Ndwiga et al (1990) for maize silages. Likewise Thomas and Wilkinson (1975) ascribed the positive effects of urea and bicarbonate in maize silage to metabolic rather than ruminal mechanisms.

Three possible explanations emerge from the published reports on this topic. The first hypothesis is that some silages have an 'acidosis' effect. When silages with a high organic acid (lactic acid and VFA) content are fed (McLeod et al, 1970; Thomas and
Wilkinson, 1975), the acid-base equilibrium of the organism is naturally disturbed, and evidence of acidosis is shown by the low $\mathrm{pH}$ of the urine. Neutralization by means of bicarbonate would then have a positive effect.

The second suggestion is that the animal's ability to rapidly metabolize the large amounts of organic acids ingested is limited because it lacks the energy (glucose) required for its metabolic functions (England and Gill, 1985; Gill et al, 1988). This can occur when the silages have a high organic acid content (acetic acid and lactic acid rapidly transformed into VFA in the rumen). The high VFA concentrations in the rumen or circulating blood may induce feedback signals and thereby limit voluntary intake.

The third explanation is that an amino acid shortage in the tissues limits appetite. This hypothesis was widely investigated following the studies of Hutchinson et al (1971), which did not confirm it, and Wilkins (1974), who observed a positive effect of amino acids fed in the form of blood meal. It was later supported by two reports (Thomas et al, 1980; Gill et al, 1987). Gill et al (1986), however, estimated that it did not apply to well-preserved silages.

In a recent study, Phillip and Simpson (1992) tried, but failed, to produce evidence for the effects of physiological mechanisms. The involvement of physiological mechanisms cannot be excluded, but they probably have a negative effect in specific situations, with particular silages.

\section{Conclusion}

It is evident that the voluntary intake of grass silages is regulated by a number of mechanisms. The effects of a single mechanism, or a combination of interfering mechanisms, depend on the type of silage and its fer- 
mentation quality. These vary widely in published reports. Although the results from the literature are sometimes debatable, the main trend is always towards a lower intake when the silage quality decreases. When the silage tested does not respond to one or more intake-regulating mechanisms, the result is always interesting, indicating that no effect exists concerning the studied mechanisms. However, in many studies the results are difficult to interpret because, regrettably, no proper control diet, such as high quality hay or fresh forage, was used.

To sum up, it is unlikely that digestive mechanisms exert a limiting effect. There is evidence to suggest that oropharyngeal mechanisms are involved, and mechanisms protecting the rumen or the total organism, or both, against an excessive supply of components that are difficult to eliminate rapidly.

\section{INTERFERING SILAGE FACTORS}

During the intake of precision-chopped silages, it appears that fermentation products rapidly produce a state of satiation, which prevents the rumen from using its entire capacity. In studies on sheep, in which the phenomenon was observed (Dulphy, 1985), the effect was ascribed to organic acids (VFA and lactic acid) in the silage and to the products of protein degradation. The influence of these products was increased when the silage was poorly preserved. The water content of the silage also seems to have a negative effect, especially for bovines.

With poorly-preserved silages there are two types of mechanisms that reduce daily intake: 1) mechanisms that reduce the duration or the volume of the meal, or both; and 2) mechanisms that reduce the number of meals per day. With precision-chopped silages the latter has a minor influence on daily intake, but it is significant with silages from long material (Dulphy and Demarquilly, 1973). Fewer meals per day indicate a greater persistence of the physical or chemical factors that delay intake.

Taking into account the hypotheses mentioned above, it is evident that, with regards to intake, animals are sensitive to silage and fermentation characteristics: factors such as acidity, osmolality, $\mathrm{pH}$, and some $\mathrm{N}$ products affect short-term (meal) intake regulation mechanisms, and moisture content, amino acid and energy balance, have longer-term effects (one or more days).

\section{Influence of general silage characteristics}

\section{Acidity and $\mathrm{pH}$}

Beginning with the work of Harris et al (1966) the $\mathrm{pH}$ and/or acidity (due to the presence of tree acids) of silage have been suggested as factors responsible for the differences in silage intake. However, studies comparing different silages of naturally differing $\mathrm{pH}$ have yielded diametrically opposed results: intake decreases when silage pH increases (Demarquilly, 1973; Dulphy and Michalet-Doreau, 1981), or intake increases when silage $\mathrm{pH}$ increases (Wilkins et al, 1971; Brown and Radcliffe, 1972; Shaver et al, 1985; Erdman, 1988).

In the first case it is obvious that acidity is not involved. The effect of silage $\mathrm{pH}$ on intake seems to be a direct consequence of the poorer fermentation quality, because higher concentrations of ammonia, acetic acid, and other buffering constituents increase silage $\mathrm{pH}$. In the second case, the positive effect of $\mathrm{pH}$ implies, above all, a decrease in acidity, caused by lower active fermentation (with wilted forages or forages containing a low quantity of sugars, but preserved with an efficient additive) without excessive formation of $\mathrm{NH}_{3}$ and VFA. 
The negative effects of acidity on intake are especially apparent with perennial ryegrass (Wilkins et al, 1978) and maize silages. In these cases the effects are not masked by the presence of ammonia. In maize silages acidity is generally negatively linked to DM, and cattle are very sensitive to these factors (Malterre, 1976). The effect on intake of maize silages with low DM is therefore comparable to that of well-acidified grass silages.

The influence of acidity on intake was mainly determined by the neutralization of acid silages before feeding. Extensive research has been undertaken on this subject (Shaver et al, 1985; Gill et al, 1988; Thomas and Thomas, 1988). In several studies neutralization did lead to higher silage intake (McLeod et al, 1970; Thomas and Wilkinson, 1975; Shaver et al, 1985; Erdman, 1988; Ndwiga et al, 1990), but in other studies no effect was observed (Wilkins, 1974; Fahran and Thomas, 1978; Snyder et al, 1983; Phillip and Hidalgo, 1989). In the latter studies the acidity was probably low or insufficient to affect intake. The addition of acids can lower the intake (see the section on the effects of lactic and acetic acids), but when they were added to silage and the $\mathrm{pH}$ was kept constant, no reduction in intake was observed (Hutchinson et al, 1971).

The concentration of free acids in silage seems to have more influence on the intake than the absolute $\mathrm{pH}$ of the silage. Miettinen et al (1991) observed no reduction of intake with $60 \mathrm{~g} / \mathrm{kg} \mathrm{DM}$ of free acids (including $20 \mathrm{~g}$ of acetic acid), but a $30 \%$ intake reduction when the free acid concentration was $130 \mathrm{~g} / \mathrm{kg} \mathrm{DM} \mathrm{(70} \mathrm{g} \mathrm{of} \mathrm{acetic} \mathrm{acid).} \mathrm{For}$ the same silages, if the quantity of acetic plus lactic acids was $50 \mathrm{~g}$, the reduction of intake was $5 \%$, and $30 \%$ with $200 \mathrm{~g}$ of these acids.

Silage acidity can be detected by chemoreceptors in the rumen, or in the organs, if metabolite concentration thresholds are sur- passed. However according to Phillip and Hidalgo (1989), silage intake does not lead to disturbances in the animal acid balance. In addition, it is difficult to separate the absolute influence of silage acidity on the intake from that of acidity induced by fermentation in the rumen. This differentiation is only possible for silage with a high DM and very low acid content. The effects of silage acidity and rumen fermentation on the intake of acid-rich silage are probably cumulative.

Curiously, for maize silages, sheep seem not to be sensitive to acidity (neither are they sensitive to DM; Demarquiliy, 1994). This is perhaps because, in that situation, another mechanism of intake control is predominant. Indeed, for the same digestibility value (72) fresh grass is always ingested faster than fresh maize, probably because of the high quantity of rapidly fermentative components in maize. The result is a relatively low intake of low-fermented silages and, as a consequence, a very small effect of an increase in fermentation products, particularly acids.

\section{Osmotic pressure}

Few studies have been made of the influence of silage osmotic pressure on intake. Phillip et al (1981b) formulated the hypothesis that high silage osmolality has a negative effect on intake. There is indeed a negative relation between rumen osmolality and intake, with intake totally ceasing at a rumen osmolality of $550 \mathrm{mosmol} / \mathrm{kg}$. This variable may, therefore, have an effect, but it is probably only a limited one. Teller et al (1989) found the highest rumen osmolality for the silage with the highest intake. Chiofalo et al (1992) also found the highest rumen osmolality for hay, which was ingested in greater quantities than the silages used in the same study. In contrast, the rumen osmolality increased more quickly for poorlypreserved silages. However, all variations in osmolality were small during the day. 


\section{Moisture content}

It has long been known that increasing silage dry matter, by wilting the grass, improves intake (Dodsworth and Campbell, 1953; Dodsworth, 1954; Thomas et al, 1961; Jackson and Forbes, 1970; Wilkins et al, 1971; Demarquilly, 1973).

As with fresh forages (Vérité and Journet, 1970), excessive amounts of water in forage probably have a negative influence on rumen fill. Thus Duckworth and Shirlaw (1958) found a decrease in intake with a DM content lower than 24-28\%. However this hypothesis is not in agreement with the fact that, with silage rations, full rumen capacity is not used. Moreover bovines are more sensitive to DM content in silage than sheep, probably indicating the greater sensitivity of cattle to the preservation quality, which is, generally, highly related to DM content.

Several authors have studied the direct influence of water on forage intake. The addition of water to hay did not modify DM intake in relation to that of dry hay (Hillman et al, 1958; Thomas et al, 1961; Clancy et al, 1977a). Drying silage did not improve intake either (Thomas et al, 1961; Clancy et al, 1977a). The negative effect of the addition of water on maize intake observed by Shaver et al (1985) was at variance with the results of Thomas et al (1961).

Finally, it seems that the relationship between silage moisture content and intake is more statistical than causal (Thomas et al, 1961), and that the negative effects of the water content are due to higher concentrations of fermentation products, a variable that is positively related to silage moisture content. Nevertheless the DM content is always a good predictor of intake.

\section{Balance between silage protein content and energy}

An amino acid supply that does not meet the animals metabolic needs also leads to a decrease in intake. This was clearly demonstrated with low quality forages by Egan (1965) and by Papas et al (1974), who found increased intake after an abomasal casein infusion. Likewise, the low protein level in maize silages, if they are unsupplemented, can negatively affect intake (Andrieu and Demarquilly, 1974; Thomas et al, 1975). Many studies have used grass silages as a result.

Hutchinson et al (1971) did not improve rye-grass silage intake by infusing casein post-ruminally. Wilkins (1974) found that supplementation with blood meal had a positive effect on the intake of cereal wholecrop silage. A proper control in the form of fresh forage, however, was not included in this study. Replacing the non-protein nitrogen in silage by true protein (Barry et al, 1978a) can, with certain types of silage, positively affect the intake. Almost no effect was observed with good quality silages (Gill et al, 1987), but a significant improvement was obtained with poor quality silages (Gill and England, 1984). This explains why positive effects were observed in some studies (Gill and Ulyatt, 1977; Thomas et al, 1980; England and Gill, 1985; Veira et al, 1988), and no difference occurred in others (Waldo et al, 1972; Kelly and Thomas, 1975; Veira et al, 1988; Phillip and Simpson, 1992).

It is therefore possible that the nitrogen composition of silage affects intake when the protein to total N ratio is too low. Worthwhile conclusions from the study of these factors can only be obtained, however, if a proper control silage is used. With bad and poorly-preserved silages in particular, therefore, there is always the risk that the animals receive an insufficient protein supply.

\section{Influence of specific acids}

According to published reports, several specific acids present in silage, such as lactic and acetic acids which are present in the 
highest concentrations, and also butyric, propionic and $\gamma$-amino butyric acids, have negative effects on intake.

\section{Acetic acid}

It is known that the detection of a high concentration of acetic acid by the rumen chemo-receptors limits intake (Baile and Mayer, 1970; Forbes, 1980; Baile and Della Fera, 1988). The influence of this acid is often cited, because of the highly negative relationship between the silage acetic acid content and the silage intake (Wilkins et al, 1971; Brown and Radcliffe, 1972; Demarquilly, 1973; Dulphy and Michalet-Doreau, 1981; Miettinen et al, 1991). Attempts to quantify the direct effect of acetic acid, however, have yielded discrepant results. Ulyatt (1965) found a lower intake after intra-ruminal infusion of acetic acid. A negative effect was also observed by Dinius et al (1968) and Gill et al (1988). The latter authors, however, found that simultaneous infusion of glucose into the duodenum limited this negative effect.

Controversially, Hutchinson and Wilkins (1971) found no significant effect for acetic acid, per se, on intake. Indeed, they observed a reduction in intake only when acetic acid was infused without being buffered. When the $\mathrm{pH}$ was held constant, the addition of acetic acid in amounts ranging from $20-88 \mathrm{~g} / \mathrm{kg}$ DM had no effect on daily intake, except for a slightly lower intake during the main meal. Similar findings were reported by Phillip et al (1981a): no effect during the day, but a slight, nonsignificant, short-term effect during the main meal. De Jong (1986) showed that acetic acid (like the other VFAs) is a factor that, under normal conditions, has a limited effect on meal size. To obtain significant effects for this variable, authors often use high doses (Gill et al, 1988). Finally, Mbanya et al (1993) also rejected the hypothesis that acetic acid alone negatively affects intake when it is given in physiological concentrations.

In conclusion acetic acid can act negatively on intake during meals when for a short time a relatively high dose is ingested, as happens with high intake rates. We suggest that the signal generated by acetic acid must be integrated with others, such as acidity and $\mathrm{pH}$. The reaction of the animals is probably then proportional to the sum of all the received signals. High concentrations of acetic acid in silage can also have negative oropharyngeal effects (Buchanan-Smith, 1990; Gherardi and Black, 1991).

\section{Propionic acid}

The effect of propionic acid has not been extensively studied, because it only occurs at low concentrations in silage. Nevertheless high ruminal concentrations can lead to lower intake (Baile and Forbes, 1974; Farningham and Whyte, 1993) if the rumen production of this acid is high. Simkins et al (1965) observed lower intake after ruminal infusions, and Brown and Radcliffe (1972) found a negative relation between silage propionic acid concentration and intake $(r=$ -0.55). However Thomas et al (1961) observed no reduction in hay intake after the addition of propionic acid, and intraruminal infusions of propionate salts did not affect intake either (Nbanya et al, 1993).

Given the low concentration of this acid in silages, its effect can be considered as secondary. However lactic acid is rapidly transformed in propionic acid in the rumen (Chamberlain and Choung, 1993; Van Vuuren et al, 1995). It would therefore be interesting to reexamine a possible effect of propionic acid.

\section{Butyric acid}

Although the concentrations of butyric acid in silage can be high, there have been few 
studies of the effect of this VFA on the intake level. There is often a negative relation between silage butyric acid concentration and intake (Demarquilly, 1973; Rook and Gill, 1990), but a direct effect for butyric acid is not clear. Gherardi and Black (1991) even found a positive effect for butyric acid on palatibility. Butyric acid thus can be considered as a good indicator of preservation quality, but its direct effect on intake and palatibility seems to be limited. It is also worth remembering that many silages do not contain this acid.

\section{$\gamma$-aminobutyric acid}

This acid is found in some silages at low concentrations. As an $\mathrm{N}$-containing compound it can represent $1-6 \%$ of the total $\mathrm{N}$ content, depending on preservation quality. Buchanan-Smith and Phillip (1986) found a depressing effect of $\gamma$-aminobutyric acid on the intake during a meal following intraruminal infusions. The dose infused, however, was high (40 g) and probably exceeded normal concentrations.

\section{Lactic acid}

Statistically the role of lactic acid is different from that of the VFAs. In regression equations, with concentrations up to about $100 \mathrm{~g} / \mathrm{kg} \mathrm{DM}$, it was generally positively related to intake (Wilkins et al, 1971; Demarquilly, 1973). This probably means that within this range, increased concentrations of lactic acid reflect better preservation. However, in nearly all studies in which the direct effect of lactic acid on intake was tested, the results yielded either no effect or a negative one. Only Senel and Owen (1966) found a higher level of intake after the addition of lactate. In another study, the addition of lactic acid to pelleted concentrate did not affect intake in sheep (Morgan and L'Estrange, 1977).
A negative effect of a combination of lactic and acetic acids was found by Thomas et al (1961). This effect was quantified by Miettinen et al (1991), who obtained a $30 \%$ reduction in intake for dairy cows with $70 \mathrm{~g}$ acetic acid and $110 \mathrm{~g}$ lactic acid/kg DM. Likewise Harris et al (1966) hypothesized that lactic acid has a negative effect on intake, especially in lambs. McLeod et al (1970) found a $22 \%$ reduction in intake for silage to which lactic acid had been added. Morgan and I'Estrange (1976) observed an intake reduction of $13 \%$ in sheep versus $7 \%$ in cattle for feed containing $65 \mathrm{~g} / \mathrm{kg} \mathrm{DM} \mathrm{lac-}$ tic acid. The intake reduction of this study was not caused by blood acidosis because, in the rumen, lactic acid is rapidly transformed into VFA. Ruminal infusions of lactic acid confirmed its negative effect on intake (Morgan and L'Estrange, 1977). Thomas et al (1980) also observed a lower intake when lactic acid concentrations were increased from 135 to $180 \mathrm{~g} / \mathrm{kg} \mathrm{DM}$, but showed that the negative effect could be reduced through the addition of fish meal. This finding, however, was not supported by the results of Choung and Chamberlain (1993), who observed that the negative effect of lactic acid on intake was not reduced by casein supplementation postruminally. Finally Jones et al (1980), and Gill et al (1988) found a negative relationship between lactic acid concentration and intake.

There is clear evidence, therefore, that a high content of lactic acid has a negative effect on intake, especially with regards to short-term regulation. Bueno (1975) showed that feedback signals for intake come from chemo-receptors in the duodenum which become activated when concentrations are above a certain threshold. McCullough (1966) observed a delayed rumination after rapid ingestion of silage containing high concentrations of lactic acid. In the rumen, lactic acid is rapidly transformed into VFA (principally propionic acid). Its direct effect must, therefore, be considered on the short term. 


\section{Conclusion}

Numerous studies have shown that low concentrations of organic acids in silage have no impact on intake. When they occur in higher concentrations they tend to reduce silage intake; the concentration of lactic acid, however, relates positively to intake levels. In high concentrations, organic acids together negatively influence intake, because their effects are additive. This notion of a cumulative process is important and seems to be gaining acceptance (Adams and Forbes, 1981; Anil et al, 1987; Mbanya et al, 1993). The rapid satiety observed in animals consuming silages could therefore be due to acids acting simultaneously, in which case their negative effects could be limited by buffers. With a high intake rate, satiety could be accentuated because not enough saliva is produced during ingestion.

Finally the interpretation of results is difficult because the effects attributed to acids could be due to a hypertonicity of the ruminal contents when cations such as $\mathrm{Na}$ and $K$ are ingested at the same time.

\section{Protein degradation products}

The main protein degradation products formed during fermentation are ammonia, free amino acids, $\mathrm{N}$-containing acids (such as $\alpha$-aminobutyric, $\gamma$-aminobutyric and $\delta$ aminovaleric acids), amines and small quantities of other compounds (Voss, 1966; Barry et al, 1978b; McDonald et al, 1991). These products become more concentrated in silage if the preservation is poor, and may therefore affect intake. It is also known that $\gamma$-aminobutyric is a neurotransmitter which inhibits intake, and that several of the biogenic amines formed in silage are toxic.

\section{Ammonia}

Studies generally show a negative relation between the ammonia concentration in silage, expressed as a percentage of the total $\mathrm{N}$ content, and the silage intake (Wilkins et al, 1971; Demarquilly, 1973; Wilkins et al, 1978; Dulphy and Michalet-Doreau, 1981; Rook and Gill, 1990). Miettinen et al (1991) even reported negative relations between the concentration of ammonia and amines together, expressed either as a percentage of DM or of the soluble N. However Rook and Gill (1990) suggested that the direct effect of ammonia on intake is low, but that its influence is related to that of other fermentation components, such as VFA and probably other $\mathrm{N}$-containing products. This could explain the lower degree of correlation between the ammonia content and intake when the concentrations are expressed in terms of DM, instead of on the basis of total $\mathrm{N}$ content.

The effect of ammonia must be limited because Choung et al (1990) found that dairy cows fed on silage with urea had a lower intake only when the crude protein (CP) of diets was more than $17 \%$, and there was high non-protein $\mathrm{N}$ content and very high ammonia content in the rumen. The animals have a high hepatic ability to transform ammonia into urea and limit its toxicity (Symonds et al, 1981). Intake may be limited only at high levels of nitrogen. This is also supported by the fact that no intake reduction was observed in sheep offered ammonia-treated hays (Benhamed and Dulphy, 1986), and that the intake of treated maize silage was even higher than that of its control (Demarquilly et al, 1971; Heinrichs and Conrad, 1984). Furthermore the addition of $\mathrm{NH}_{3}$ to silage, even when the $\mathrm{pH}$ increased from 4.5 to 5.5 , did not influence the intake leveis (Wilkins, 1974). Van Os et al (1995a, b) also observed no effect of addition of $\mathrm{NH}_{3}$ to a silage fed to sheep and dairy cows. 
In intermediary metabolism, ammonia remains a toxic agent and is transformed by the liver into urea. High ruminal concentrations of ammonia reduced the duration of the following main meal (Conrad et al, 1977). Something comparable may occur during the ingestion of poorly-preserved silages high in ammonia. For silages with high and low ammonia contents, similar daily DM intake was observed with both, but earlier states of satiation were obtained with the silage of high ammonia content (Deschard et al, 1987). Thomas et al (1961) also reported negative effects of ammonia, but only with the use of very high doses, rarely found in silages.

At the oropharyngeal level, ammonia does not seem to affect the intake (Buchanan-Smith, 1990). This is consistent with the finding of a higher intake of ammonia-treated hays (Benhamed and Dulphy, 1986). However, for similar DM intake, Heinrichs and Conrad (1984) observed that the animals took fewer meals when fed ammonia-treated silages.

Although ammonia is widely used as an indicator of silage quality, its influence on intake remains unclear. It is, however, almost certain that, in very low quality silages, high concentrations of ammonia affect intake (Choung et al, 1990). Nevertheless, for all kinds of silages, ammonia (expressed as the percentage of total $\mathrm{N}$ ) remains a good parameter to characterize quality and to predict intake.

\section{Amines}

During bad silage fermentation, protein degradation occurs, yielding amines at concentrations up to $8 \mathrm{~g} / \mathrm{kg}$.DM (Tveit et al, 1992); however they are also formed in wellfermented grass silages (Van Os et al, 1996). It has long been assumed that these amines negatively influence silage intake (Neumark et al, 1964), either at the oropharyngeal level or through their physiological effects (Voss, 1966). Neumark et al (1964) even found a negative relation between silage tryptamine content and intake. McDonald et al (1963) and Okamoto et al (1964) were unable to detect any direct influence of histamine on silage intake, perhaps because the levels of histamine were too low. Barry et al (1978a) put forward the same hypothesis, because of the large amounts of amines formed in silages (Voss, 1966).

Buchanan-Smith and Phillip (1986) observed a short term decrease in intake after giving ruminal infusions of mixtures of amines frequently found in silages. No effect, however, was found from a mixture of putrescine, cadaverine and $\gamma$-aminobutyric acids at the oropharyngeal level (BuchananSmith, 1990).

From the recent studies of Van Os et al (1995a, 1995b) and Van Os and Van Vuuren (1996) it seems that the effects of amines are small. An effect on palatibility seems evident, but animals adapted after about 14 days. Post-ingestive effects are also possible because amines are toxic compounds, but the ruminal content can adapt to destroy amines (Van Os et al, 1995c; Van Os and Van Vuuren, 1996) and rapidly limits their potential effect. Therefore, a small decrease of intake is observed in a first trial with sheep, but not with dairy cows. No effects on total intake were observed in two other trials with sheep (Van Os et al, 1995d; Van Os and Van Vuuren, 1996), although a negative effect on palatibility remained.

\section{Other fermentation products}

Clancy et al (1977b) compared the influences on intake of ruminal infusions of juice pressed from silage and artificially composed silage juice, and concluded that other unknown or unmeasured fermentation products may affect the intake. 
The way in which products are added to silage (eg, by mixing, or by rapid or slow rumen infusion) is very important and the ingestive behaviour of the animals must be taken into consideration. The rate of intake is always high and the effect of many soluble products may be short and therefore difficult to observe.

\section{DISCUSSION AND GENERAL CONCLUSIONS}

Many fermentation products, considered separately but at fairly high levels, have a negative effect on the DM intake. For product levels normally observed in silages we must consider simultaneously the cumulative effects of different components, and the effect of different components in different silages. This explains somewhat the complexity of studies on silages and the differences in their results and interpretation. The associated effects of different physiological systems for intake control must also be considered (oropharyngeal, ruminal and metabolic; Forbes, 1986). No single effect is able to explain all observations (Mbanya et al, 1993).

The influence of fermentation products on the intake-regulating mechanisms seems to occur mainly via chemostatic regulation in the rumen or through intermediary metabolism. Influence at the oropharyngeal level seems to be of minor importance, except when silages contain high concentrations of fermentation compounds. This probably explains the rapid satiety observed during the main meal, a typical intake pattern which prevents disturbances in the animal's homeostasis and that can be learned during the first few days of the distribution. The number and size of the small meals thereafter probably depends on the disappearance of the state of satiation and on the sensory attributes of the silage.

Under these conditions, the mechanisms regulating homeostasis would play a deter- mining role, which is a classical law in physiology. Animals would be obliged to limit their intake to avoid metabolic disturbances. The correction of these problems (by buffers, amino acids, etc) often results in a higher intake.

The rapid achievement of satiety is unique to silage diets and is probably related to a high rate of intake and the fact that, with silages, rumen capacity is not used to its fullest extent. In contrast, these mechanisms seem to have little effect on small meals.

As silage intake is governed by numerous factors it is difficult to determine the individual role of the different regulatory mechanisms involved and to quantify the controlling influences of the different factors. However, as our knowledge of intake regulation advances so does our understanding of the mechanisms governing them.

Methods exist for making a good quality silage which will lead to high levels of intake (Van Vuuren et al, 1995). This silage may be slightly wilted (25\% DM) and preserved with an efficient additive. It can be also wilted ( $35 \% \mathrm{DM})$, but in this case, if intake is normally high, digestibility and value for milk production decrease. These two kinds of silage result in an intake similar to that of the corresponding fresh forage or barn-dried hay, presumably because they contain a low concentration of fermentation products.

Two other types of silage are also available: 1) well-preserved direct silages from low dry matter maize or perennial rye-grass, but with a low $\mathrm{pH}$ and a high level of free acids: the DM intake is low, because of the acids; acetic and lactic acid may also have specific negative effects; and 2) poorly preserved direct-cut silages from grasses and legumes, with high levels of ammonia, amines and butyric acid and a relatively high $\mathrm{pH}$; the more poorly they are preserved the greater is the decrease in the resulting intake. The factors involved are numerous 
and their effects are probably cumulative (eg, moisture, VFA, ammonia, amines and $\gamma$-aminobutyric acid), with unknown compounds possibly having specific influence. Hence it is perhaps not advantageous to know precisely which factors cause low intake, but statistical relations between some parameters and intake are very interesting.

In conclusion, considerable advances have been made in our knowledge of intake control of silage DM by ruminants. Many questions remain however. It is probable that current studies are more efficient than those made 30 years ago, but there is far less research now into the topic because well ingested silages are, in theory, easy to prepare.

\section{REFERENCES}

Adams GB, Forbes JM (1981) Additivity of effects of ruminal acetate and either portal propionate or rumen distension on food intake in sheep (Abstr). Proc Nutr Soc $40,44 \mathrm{~A}$

Andrieu J, Demarquilly C (1974) Valeur alimentaire du maïs fourrage. II. Influence du stade de végétation, de la variété, du peuplement, de l'enrichissement en épis et de l'addition d'urée sur la digestibilité et l'ingestibilité de l'ensilage de maïs. Ann Zootech 23, $1-25$

Andrieu J, Demarquilly C, Wegat-Litre E (1981) Tables de prévision de la valeur alimentaire des fourrages. In: Prévision de la valeur nutritive des aliments des ruminants (C Demarquilly, ed), INRA Publications, Versailles, 345-557

Anil MH, Mbanya JN, Symonds HW, Forbes JM (1987) Dose-related effects on hay intake of acetate infused into the rumen of lactating cows. Proc Nutr Soc 46, 29A

Baile CA (1975) Control of feed intake in ruminants. In: Digestion and Metabolism in the Ruminant (IW McDonald, ACI Warner, eds), University of New England Publishing Unit, Armidale, Australia, 333-350

Baile CA, Mayer J (1970) Hypothalamic centres: feedbacks and receptor sites in the short-term control of feed intake. In: Physiology of Digestion and Metabolism in the Ruminant (AT Phillipson, ed), Oriel Press, Newcastle-upon-Tyne, 254-263

Baile CA, Forbes JM (1974) Control of feed intake and regulation of energy balance in ruminants. Physiol Rev 54, 160-214
Baile CA, Deila Fera MA (1988) Physiology of control of food intake and regulation of energy balance in dairy cows. In: Nutrition and Lactation in the Dain Cow (PC Garnsworthy, ed), Butterworths, London, 251-261

Barry TN, Cook JE, Wilkins RJ (1978a) The influence of formic acid and formaldehyde additives and type of harvesting machine on the utilization of nitrogen in lucerne silages. 1. The voluntary intake and nitrogen retention of young sheep consuming the silages with and without intraperitoneal supplements of DLmethionine. J Agric Sci Camb 91, 701-715

Barry TN, Mundell DC, Wilkins RJ, Beever DE (1978b) The influence of formic acid and formaldehyde additives and type of harvesting machine on the utilization of nitrogen in lucerne silages. 2 . Changes in amino acid composition during ensiling and their influence on nutritive value. J Agric Sci Camb 91, 717-725

Baumont $R$ (1989) État de replétion du réticulo-rumen et ingestion de fourrages : incidences sur le contrôle à court terme de la quantité de foin ingérée par le mouton. PhD thesis, INA-PG Paris

Baumont R, Seguier N, Duiphy JP (1990) Rumen fill, forage palatibility and alimentary behaviour in sheep. J Agric Sci Camb 115, 277-284

Baumont R, Chiofalo V, Dulphy JP (1993) A study of the daily feed intake pattern in sheep fed at libitum orchard grass hay or silage. Ann Zootech 42, 188 (Abstr)

Benhamed H, Dulphy JP (1986) Influence du traitement des foins à l'ammoniac sur leur valeur azotée appréciée par la méthode des bilans azotés. Ann Zootech $35,387-400$

Brown DC, Radcliffe JC (1972) Relationship between intake of silage and its chemical composition and in vitro digestibility. Aust J Agric Res 23, 25-33

Buchanan-Smith JG (1990) An investigation into palatability as a factor responsible for reduced intake of silage by sheep. Anim Prod 50, 253-260

Buchanan-Smith JG, Phillip LE (1986) Food intake in sheep following intraruminal infusion of extracts from lucerne silage with particular reference to organic acids and products of protein degradation. J Agric Sci Camb 106, 611-617

Bueno L (1975) Rôle de l'acide DL-lactique dans le contrôle de l'ingestion alimentaire chez le mouton. Ann Rech Vet 6, 325-336

Campling RC (1966) The intake of hay and silage by cows. J Br Grass/ Soc 21, 41-49

Campling RC, Balch CC (1961) Factors affecting the voluntary intake of food by cows. 1. Preliminary observations on the effect, on the voluntary intake of hay, of changes in amount of reticulo-rumen contents. Br J Nutr 15, 523-530

Castle ME, Watson JN (1970) Silage and milk production, a comparison between grass silages made with and without formic acid. J Br Grass/ Soc 25, 65-70 
Chambertain DG, Choung JJ (1993) The nutritional value of grass silage. In: Proceedings of the 10th International Conference on Silage Research, Dublin City University, Ireland, September (O'Kiely, O'Connell M, Murphy J, eds), 131-136

Chiofalo V, Dulphy JP, Baumont R (1992) Influence of the method of forage conservation on feeding behaviour, intake and characteristics of reticulorumen content, in sheep fed ad libitum. Reprod Nutr Dev 32, 377-392

Choung JJ, Chamberlain DG (1993) The effect of addition of lactic acid to silage and infusion of protein into the abomasum on the intake and utilization of grass silage by the dairy cow. In: Silage Research 1993. Proceedings of the 10th International Conference on Silage Research. Dublin City University, Ireland, September (O'Kiely, O'Connell M, Murphy J, eds), 141-142

Choung JJ, Chamberlain DG, Thomas PC, Bradbury I (1990) The effects of intraruminal infusions of urea on the voluntary intake and milk production of cows receiving grass silage diets. J Dairy Res 57,455 464

Clancy M, Wangsness PJ, Baumgardt BR (1977a) Effect of conservation method on digestibility, nitrogen balance, and intake of alfalfa. J Dairy Sci $60,572-579$

Clancy M, Wangsness PJ, Baumgardt BR (1977b) Effect of silage extract on voluntary intake, rumen fluid constituents, and rumen motility. J Dairy Sci 60, 580590

Colucci PE, Grovum WL (1993) Factors affecting the voluntary intake of food by sheep. 6 . The effect of monosodium glutamate on the palatability of straw diets by sham-fed and normal animals. Br J Nutr 69 , 37-47

Conrad JR, Baile CA, Mayer J (1977) Changing meal patterns and suppression of feed intake with increasing amounts of dietary nonprotein nitrogen in ruminants. J Dairy Sci 60, 1725-1733

Corkum MJ, Bate LA, Lirette A, Tennessen T (1994) Effects of flavouring agents on intake of silage by feedlot steers. Can J Anim Sci 74, 387-389

De Jong A (1986) The role of metabolites and hormones as feedbacks in the control of feed intake in ruminants. In: Control of Digestion and Metabolism in Ruminants (LP Milligan, WL Grovum, A Dobson, eds), Prentice-Hall, Englewood Cliffs, New Jersey, $459-478$

Demarquilly C (1973) Composition chimique, caractéristiques fermentaires, digestibilité et quantité ingérée des ensilages de fourrages : modifications par rapport au fourrage vert initial. Ann Zootech 22, 1-35

Demarquilly C (1994) Facteurs de variation de la valeur nutritive du maïs ensilage. INRA Prod Anim 7, 177189

Demarquilly $C$, Haurez $P$, Joumet $M$, Lelong $C$, Malterre $C$ (1971) Le maîs plante entière : composition, valeur alimentaire, utilisation par les bovins. Bull Tech inf 264-265, 1001-1018

Deschard G, Tetlow RM, Mason VC (1987) Treatment of whole-crop cereals with alkali. 3 . Voluntary intake and digestibility studies in sheep given immature wheat ensiled with sodium hydroxyde, urea or ammonia. Anim Feed Sci Technol 18, 283-293

Dinius DA, Hill DL, Noller CH (1968) Influence of supplemental acetate feeding on the voluntary intake of cattle fed green corn and corn silage. J Dairy Sci 51, 1505-1507

Dodsworth TL (1954) Further studies on the fattening value of grass silage. J Agric Sci Camb 44, 383-393

Dodsworth TL, Campbell WHM (1953) Report on a further experiment to compare the fattening values for beef cattle, or silage made from grass cut at different stages of growth together with the results of some supplementary experiments. J Agric Sci 43, 166-177

Duckworth JE, Shirlaw DW (1958) A study of factors affecting feed intake and the eating behaviour of cattle. Anim Behav VI, 3-4, 147-154

Dulphy JP (1972) Étude de quelques relations entre le mode de conservation du fourrage ingéré et le comportement alimentaire et mérycique des moutons. Ann Zootech 21, 429-442

Dulphy JP (1985) Étude des quantités ingérées lors des grands repas chez des moutons recevant des fourrages ensilés. Ann Zootech 34, 401-416

Dulphy JP (1987) Utilisation des foins par les vaches laitières. In: Les fourrages secs : récolte, traitement, utilisation (C Demarquilly, ed), INRA, Paris, 335-359

Dulphy JP, Demarquilly C (1973) Influence de la machine de récolte et de la finesse de hachage sur la valeur alimentaire des ensilages. Ann Zootech 22, 199-217

Dulphy JP, Demarquilly C (1977) Effect of ensiling on feed intake and animal performance. In: Proceedings of the International Meeting on Animal Production from Temperate Grassland (B Gilsenan, ed), Irish Grassland and Animal Production Association, Dublin, 53-61

Dulphy JP, Demarquilly C (1981) Problèmes particuliers aux ensilages. In: Prévision de la valeur nutritive des aliments des ruminants (C Demarquilly, ed), INRA Publications, Versailles, 81-104

Dulphy JP, Michalet-Doreau B (1981) Prévision de f'ingestibilité des ensilages d'herbe. In: Prévision de la valeur nutritive des aliments des ruminants ( $C$ Demarquilly, ed), INRA Publications, Versailles, 169188

Dulphy JP, Rouel J (1988) Modifications d'ingestibilité entraînées par la fenaison chez les bovins. Comparaison avec les ovins. Ann Zootech 37, 31-42

Dulphy JP. Demarquilly C (1991) Digestibility and voluntary intake of conserved forage. In: Forage Consenvation towards 2000 (G Pahlow, H Honig, eds), European Grassland Federation, Fed Res Center of Agriculture Braunschweig, Völkenrode, 140-160 
Dulphy JP, Bechet $G$, Thomson E (1975) Influence de la structure physique et de la qualité de conservation des ensilages de graminées sur leur ingestibilité. Ann Zootech 24, 81-94

Dulphy JP, Michalet-Doreau B, Demarquilly C (1984) Étude comparée des quantités ingérées et du comportement alimentaire et mérycique d'ovins et de bovins recevant des ensilages d'herbe réalisés selon differrentes techniques. Ann Zootech 33, 291-320

Dulphy JP, Faverdin P, Micol D, Bocquier F (1987) Révision du système des unités d'encombrement (UE). Bull Tech CRZV Theix, 70, 35-48

Dulphy JP, Jamot J, Chenost M, Besle JM, Chiofalo V (1992) The influence of urea treatment on the intake of wheat straw in sheep. Ann Zootech 41, 169-185

Egan AR (1965) Nutritional status and intake regulation in sheep. III. The relationship between improvement of nitrogen status and increase in voluntary intake of low-protein roughages by sheep. Aust J Agric Res $16,463-472$

England P, Gill M (1985) The effect of fish meal and sucrose supplementation on the voluntary intake of grass silage and live-weight gain of young cattle. Anim Prod 40, 259-265

Erdman $\mathrm{R}$ (1988) Forage $\mathrm{pH}$ effects on intake in early lactation dairy cows. J Dairy Sci 712, 1198-1203

Fahran SMA, Thomas PC (1978) The effect of partial neutralization of formic acid silages with sodium bicarbonate on their voluntary intake by cattle and sheep. J Br Grass/ Soc 33, 151-158

Farningham DAF, Whyte CC (1993) The role of propionate and acetate in the control of food intake in sheep. Br J Nutr 70, 37-46

Forbes JM (1980) Hormones and metabolites in the control of food intake. In: Digestive Physiology and Metabolism in Ruminants (Y Ruckebusch, $P$ Thivend, eds), MTP Press, Lancaster, 145-160

Forbes JM (1986) The Voluntary Food Intake of Farm Animals. Butterworth, London

Gatel F (1984) Signification de la satiété à court terme chez le mouton : influence de la qualité du fourrage et des stimulus associés à la prise de nourriture. Ann Zootech 33, 111-118

Gherardi SG, Black JL (1991) Effect of palatability on voluntary feed intake by sheep. I. Identification of chemicals that alter the palatibility of a forage. Aust $J$ Agric Res 42, 571-584

Gill M, Ulyatt MJ (1977) The effect of supplementation with protein, energy and L- methionine, on the digestion of silage by sheep. J Agric Sci Camb 89, 43-51

Gill M, England P (1984) Effect of degradability of protein supplements on voluntary intake and nitrogen retention in young cattle fed grass silage. Anim Prod 39 , 31-36

Gill M, Thiago LRS, Buchanan-Smith JG (1986) Intake problems associated with ensiled forages. Feed
Intake by beef cattle. Symposium, Oklahoma State University. 341-352

Gill M, Beever DE, Buttery PJ, England P, Gibb MJ Baker RD (1987) The effect of oestradiol-17 $\beta$ implantation on the response in voluntary intake, live-weight gain and body composition, to fish meal supplemention of silage offered to growing calves. J Agric Sci Camb 108, 9-16

Gill M, Rook AJ, Thiago LRS (1988) Factors affecting the voluntary intake of roughages by the dairy cow. In: Nutrition and Lactation in the Dairy Cow (PC Garnsworthy, ed), Butterworth, London, 262-279

Greenhalgh JFD, Reid GW (1971) Relative palatibility to sheep of straw, hay and dried grass. Br J Nutr $26,107-116$

Grovum WL (1987) Appetite, palatibility and control of feed intake. In: The Ruminant Animal (DC Church, ed), Prentice Hall, Englewood Cliffs, New Jersy. 202216

Grovum WL, Chapman HW (1988) Factors affecting the voluntary intake of food by sheep. 4 . The effect of additives representing the primary tastes on sham intakes by oesophageal-fistulated sheep. $\mathrm{Br} J$ Nutr $59,63-72$

Harris CE, Raymond WF, Wilson RF (1966) The voluntary intake of silage. In: Proceedings of the 10th International Grassland Congress, Helsinki (AGG Hill, ed), 564-568

Heinrichs AJ, Conrad HR (1984) Fermentation characteristics and feeding value of ammonia-treated corn silage. J Dairy Sci $67,82-87$

Henderson AR, Anderson DH (1986) The effect of a flavor compound on the intake of silage by Wether lambs (Abstr). Anim Prod 42, 473

Hillman D, Lassiter CA, Hoffman CF, Duncan CW (1958) Effect of all-hay vs all-silage rations on dry matter intake of lactating dairy cows: moisture and $\mathrm{pH}$ as factors affecting appetite (Abstr). J Dairy Sci 41, 720

Hutchinson KJ, Wilkins RJ (1971) The voluntary intake of silage by sheep. II. The effects of acetate on silage intake. J Agric Sci Camb 77, 539-543

Hutchinson KJ, Wilkins RJ, Osbourn DF (1971) The voluntary intake of silage by sheep. III. The effects of post-ruminal infusions of casein on the intake and nitrogen retention of sheep given silage ad libitum. J Agric Sci Camb 77, 545-547

Jackson N, Forbes TJ (1970) The voluntary intake by cattle of four silages differing in dry matter content. Anim Prod 12, 591-599

Jarrige R, Demarquilly C, Dulphy JP (1981) Forage conservation. In: Nutritional Limits to Animal Production from Pastures (JB Hacker, ed), Commonwealth Agricultural Bureaux, Farnham Royal, UK 363-387

Jarrige R, Dulphy JP, Faverdin P, Baumont R, Demarquilly $C$ (1995) Activités d'ingestion et de rumination. In: Nutrition des ruminants domestiques (R Jar- 
rige, $Y$ Ruckebusch, C Demarquilly, MH Farce, M Journet, eds), INRA Éd, 123-181

Jones GM, Larsen RE, Lanning NM (1980) Prediction of silage digestibility and intake by chemical analyses or in vitro fermentation techniques. J Dairy Sci 63 , 579-586

Kelly NC, Thomas PC (1975) The effect of intravenous infusions of methionine on the voluntary intake of grass silage by sheep. J Br Grass/ Soc 30, 237-239

Kennedy SJ (1990) The effect of an acid salt-type additive on grass preservation, in-silo loss and performance of growing beef cattle. Proceedings of the 9th Silage Conference, University of Newcastle-upon Tyne. 60-61

Lawlor MJ, O'Shea J (1967) A comparison of rumen characteristics of hay versus silage-fed animals. Ir $J$ Agric Res 6, 119-121

Malterre C (1976) Utilisation du maïs sous différentes formes pour la production de viande de jeunes bovins. Bull Tech CRZV Theix, INRA, 24, 63-74

Mbanya JN, Anil MH, Forbes JM (1993) The voluntary intake of hay and silage by lactating cows in response to ruminal infusion of acetate or propionate, or both, with and without distension of the rumen by a balloon. Br J Nutr 69, 713-720

McCarrick RB, Keane E, Tobin J (1965) The nutritive value of ammonium bisulfate and molassed silages. I. Comparisons of acceptability and feeding value for beef and dairy cattle. Ir J Agric Res 4, 115-123

McCullough ME (1966) The nutritive value of silage as influenced by silage fermentation and ration supplementation. Proceedings of the 10th International Grassland Congress, Helsinki, AGG Hill Ed, 581587

McDonald P, Macpherson HT, Watt JA (1963) The effect of histamine on silage dry-matter intake. JBr Grass! Soc 18, 230-232

McDonald P, Henderson AR, Heron SJE (1991) The Biochemistry of Silage. 2nd Edition, Chalcombe Publications, Marlow, Bucks, UK

McLeod DS, Wilkins RJ (1970) The effect of intra-ruminal feeding on the intake of silage. J Agric Sci Camb $75,559-564$

McLeod DS, Wilkins RJ, Raymond WF (1970) The voluntary intake by sheep and cattle of silages differing in free-acid content. J Agric Sci Camb 75, 311-319

Michalet $B$ (1975) Recherches sur Is causes des variations des quantités d'ensilage d'herbe ingérées par les ruminants. PhD thesis, université de Nancy

Michalet-Doreau B, Gatel F (1983) Évolution au cours d'une année des quantités de foin ingérées par des béliers castrés. Ann Zootech 32, 459-464

Miettinen $H$, Setälä J, Moisio T (1991) Estimation of the effect of silage quality on silage palatibility and intake in dairy cows. In: Forage Conservation towards 2000 (G Pahlow, H Honig, eds), European Grassland Fed- eration, Fed Res Center of Agriculture Braunsehweig-Völkenrode, Mariow, Bucks, UK, 408-409

Morgan DJ, L'Estrange JL (1976) Effect of dietary additions of hydrochloric and lactic acid on feed intake and metabolism of sheep and cattle. Ir J Agric Res $15,55-63$

Morgan DJ, L'Estrange JL (1977) Voluntary feed intake and metabolism of sheep when lactic acid is administered in the feed or intraruminally. J Br Grassi SoC $32,217-224$

Ndwiga CA, Erdman RA, Vandersall JH, Sharma BK (1990) Effect of type and site of acid neutralization on voluntary intake of corn silage by dairy heifers. $J$ Dairy Sci 73, 1571-1577

Neumark $H$, Bondi A, Volcani R (1964) Amines, aldehyde and keto-acids in silages and their effect on food intake by ruminants. J Sci Food Agric 15, 487492

Okamoto M, Waldo DR, Miller RW, Moore LA (1964) Histamine levels in forages and dry matter intake of heifers. J Dairy Sci 47, 1231-1236

Orth AV, Kaufmann W (1966) Zur Wirkung von Bicarbonat auf die Futteraufnahme bei Milchkühen. $Z$ Tierernaehr Futter 21, 350-361

Papas A, Hatfield EE, Owens FN (1974) Responses of growing lambs of abomasal infusion of corn oil, starch, casein and amino-acid mixtures. J Nutr 104, 1543-1553

Phillip LE, Hidalgo V (1989) Voluntary feed intake, acidbase balance and partitionning of urinary nitrogen in lambs fed corn silage with added sodium bicarbonate or sodium sesquicarbonate. J Anim Sci 67, 2116-2122

Phillip LE, Simpson MV (1992) Differentiation of the effects of protein status and acid-base balance on the appetite of sheep for lucerne silage. J Agric Sci Camb $118,249-257$

Phillip LE, Buchanan-Smith JG, Grovum WL (1981a) Effects of infusing the rumen with acetic acid and nitrogenous constituents in maize silage extracts on food intake, ruminal osmolality and blood acid-base balance in sheep. J Agric Sci Camb 96, 429-438

Phillip LE, Buchanan-Smith JG, Grovum WL (1981b) Food intake and ruminal osmolality in sheep: differentiation of the effect of osmolality from that of the products of maize silage fermentation. J Agric Sci Camb 96, 439-445

Prates ER, Thiago LRS, Gill M, Theodorou MK (1986) The effect of conservation method and frequency of feeding on rumen microbial activity. Proc Nutr Soc 45, 95A

Rook AJ, Gill M (1990) Prediction of the voluntary intake of grass silages by beef cattle. 1 . Linear regression analyses. Anim Prod 50, 425-438

Senel SH, Owen FG (1966) Relation of dietary acetate and lactate to dry matter intake and volatile fatty acid metabolism. J Dairy Sci 49, 1075 
Shaver RD, Erdman RA, O'Connor AM, Vandersall JH (1985) Effects of silage $\mathrm{pH}$ on voluntary intake of corn silage and alfalfa haylage. J Dairy Sci 68, 338346

Simkins KL Jr, Suttle JW, Baumgardt BR (1965) Regulation of food intake in ruminants. 4. Effect of acetate, propionate, butyrate, and glucose on voluntary food intake in dairy cattle. J Dairy Sci 48, 1635-1642

Sissons JW, Gill M, Thiago LRS (1986) Effect of conservation method and frequency of feeding on forestomach motility. Proc Nutr Soc 45, 96A

Snyder TJ, Rogers JA, Muller LD (1983) Effects of $1.2 \%$ sodium bicarbonate with two ratios of corn silage: grain on milk production, rumen fermentation and nutrient digestion by lactating dairy cows. J Dairy Sci 66, 1290-1297

Symonds HW, Mather DL, Collis KA (1981) The maximum capacity of the liver of the adult dairy cow to metabolize ammonia. Br J Nutr 46, 481-486

Teller E, Vanbelle M, Kamatali P, Wavreille J (1989) Intake of direct cut or wilted grass silage as related to chewing behavior, ruminal characteristics and site and extent of digestion by heifers. J Anim Sci 67, 2802-2809

Thiago LRS, Gill M (1986) The effect of conservation method and frequency of feeding on the removal of digesta from the rumen. Proc Nutr Soc 45, $97 \mathrm{~A}$

Thiago LRS, Gill M, Dhanoa MS (1992a) Studies of method of conserving grass herbage and frequency of feeding in cattle. 1. Voluntary feed intake, digestion and rate of passage. Br J Nutr 67, 305-318

Thiago LRS, Gill M, Sissons W (1992b) Studies of method of conserving grass herbage and frequency of feeding in cattle. 2. Eating behaviour, rumen motility and rumen fill. Br J Nutr 67, 319-336

Thomas C, Wilkinson JM (1975) The utilization of maize silage for intensive beef production. 3. Nitrogen and acidity as factors affecting the nutritive value of ensiled maize. J Agric Sci Camb 85, 255-261

Thomas C, Thomas PC (1988) Factors affecting the nutritive value of grass silages. In: Nutrition and Lactation in the Dairy Cow (PC Gansworthy, ed), Butterworths, London, 223-256

Thomas JW, Moore LA, Okamoto M, Sykes JF (1961) A study of factors affecting rate of intake of heifers fed silage. J Dairy Sci 44, 1471-1483

Thomas C, Wilson RF, Wilkins RJ, Wilkinson JM (1975) The utilization of maize silage for intensive beef production. II. The effect of urea on silage fermentation and on the voluntary intake and performance of young cattle fed maize silage-based diets. J Agric Sci Camb 84, 365-372

Thomas C, Gill M, Austin AR (1980) The effect of supplements of fish meal and lactic acid on voluntary intake of silage by calves. Grass Forage Sci 35, 275279
Tveit B, Lingaas F, Svendsen, Sjaasted ØV (1992) Etiology of acetonemia in Norwegian cattle. 1. Effect of ketogenic silage, season, energy level and genetic factors. J Dairy Sci 75, 2421-2432

Ulyatt MJ (1965) The effects of intra-ruminal infusions of volatile fatty acids on food intake of sheep. $N Z J$ Agric Res 8, 397-408

Van Bruchem J, Bosch MW, Lammers Weinhoven SCW, Bangma GA (1991) Intake, rumination reticulo-rumen fluid and particle kinetics, and faecal particle size in heifers and cattle fed on grass hay wilted grass silage. Livest Prod Sci 27, 297-308

Van Os M, Van Vuuren AM (1996) Mechanisms of adaptation in sheep to overcome silage intake depression induced by biogenic amines. Br J Nutr (in press)

Van Os M, Dulphy JP, Baumont R (1995a) The effect of protein degradation products in grass silages on feed intake and intake behaviour in sheep. Br J Nutr $73,51-64$

Van Os M, Dulphy JP, Baumont R (1995b) The influence of ammonia and amines on grass silage intake and intake behaviour in dairy cows. Ann Zootech $44,73-85$

Van Os M, Lassalas B, Toillon S, Jouany JP (1995c) In vitro degradation of amines by rumen micro-organisms. J Agric Sci 125, 299-305

Van Os M, Jailler M, Dulphy JP (1995d) The influence of nitrogenous components on grass silage intake in sheep. Br J Nutr (in press)

Van Os M, Van Wikselaar PG, Spoelstra SF (1996) Formation of biogenic amines in well-fermented grass silages. J Agric Sci (in press)

Van Vuuren AM (1994) Aspects of forage intake reguIation. In: Proc 15th General Meeting of the European Grassland Federation (L't Mannetje, J Frame, eds), Grassland and Society, Wageningen Pers, Wageningen, 556-565

Van Vuuren AM, Huhtanen P, Dulphy JP (1995) Improving the feeding and health value of ensiled forages. In: Recent Developments in the Nutrition of Herbivores ( $M$ Journet, $E$ Grenet, MH Farce, M Thériez, C Demarquilly, eds), INRA Éditions, Paris, 279-307

Veira DM, Proulx JG, Butler G, Fortin A (1988) Utilization of grass silage by cattle: further observations on the effect of fish meal. Can J Anim Sci 68, 12251235

Vérité $R$, Journet $M(1970)$ Influence de la teneur en eau et de la déshydratation de l'herbe sur sa valeur alimentaire pour les vaches laitières. Ann Zootech 19, 255-268

Voss $N$ (1966) Amines and ammonia as products of protein decomposition in silage. Proc $X$ Int Grassland Congress University of Helsinki, Finland, 7-16 July 1996 (AGG Hill, ed), 540-546

Waldo DR (1977) Potential of chemical perservation and improvment of forages. J Dairy Sci 60, 306-323 
Waldo DR, Miller RW, Okamoto M, Moore LA (1965) Ruminant utilization of silage in relation to hay, pellets and hay plus grain. II. Rumen content, dry-matter passage and water intake. J Dairy Sci 48, 14731480

Waldo DR, Smith LW, Gordon GH (1968) Formic acid silage versus untreated silage for growth (Abstr). $J$ Dairy Sci 51, 982

Waldo DR, Keys Jr JE, Smith LW, Gordon CH (1971) Effect of formic acid on recovery, intake, digestibility and growth from unwilted silage. J Dairy Sci 54,77 84

Waldo DR, Keys Jr JE, Oltjen RR, Gordon $\mathrm{CH}$ (1972) Protein quality and $\mathrm{N}$ infusion effects on plasma amino acids and silage intake (Abstr). J Anim Sci 35,235
Waldo DR, Keys Jr JE, Gordon CH (1975) Paraformaldehyde compared with formic acid as a direct-cut silage preservative. J Dairy Sci 58, 922-930

Wilkins RJ (1974) The effects of partial neutralization with sodium bicarbonate or ammonia and the feeding of blood meal on the voluntary intake of a wholecrop barley silage by sheep. Anim Prod 19, 87-91

Wilkins RJ, Hutchinson KJ, Wilson RF, Harris CE (1971) The voluntary intake of silage by sheep. I. Interrelationships between silage composition and intake. J Agric Sci Camb 77, 531-537

Wilkins RJ, Fenlon JS, Cook JS, Wilson RF (1978) A further analysis of relationship between silage composition and voluntary intake by sheep. Proceedings of the 5th Silage Conference, West of Scotland College of Agriculture, Ayr, 34-35 